\title{
Leucyl-tRNA synthetase: double duty in amino acid sensing
}

Raúl V Durán, Michael N Hall

Cell Research (2012) 22:1509. doi:10.1038/cr.2012.138; published online 1 October 2012

Due to a production error by the editorial office, this Research Highlight, which was originally published in the August issue of Cell Research (22:1207-1209. doi:10.1038/cr.2012.68; published online 24 April 2012), was inadvertently duplicated in the September issue (22:1312-1314). This duplicate Highlight is now removed from the online September issue. We apologize to the readers and the authors for any inconvenience or confusion that may have been caused by this error. 